\title{
Contract Hope and Sovereign Redemption
}

Anna Gelpern

Georgetown University Law Center, ag1348@law.georgetown.edu

This paper can be downloaded free of charge from:

https://scholarship.law.georgetown.edu/facpub/1315

http://ssrn.com/abstract=2203123

8 Cap. Markets L.J. 132-148 (2013)

This open-access article is brought to you by the Georgetown Law Library. Posted with permission of the author. Follow this and additional works at: https://scholarship.law.georgetown.edu/facpub

Part of the Administrative Law Commons, Banking and Finance Law Commons, Bankruptcy Law Commons, and the Finance Commons 


\title{
Contract hope and sovereign redemption
}

\author{
Anna Gelpern*
}

\section{Key points}

- Sovereign immunity has served as a partial substitute for bankruptcy protection, but it has encouraged a minority of creditors to pursue unorthodox legal remedies with spillover effects beyond the debtorcreditor relationship.

- The attempt to enforce Argentina's pari passu clause in New York points to one such remedy, which relies primarily on collateral damage to other creditors and market infrastructure to obtain settlement from a debtor that would not pay.

- The District Court decision, now on appeal before the Second Circuit, may not make holding out more attractive in future restructurings - but it would make participation less attractive for creditors, and would create uncertainty for trustees, clearing and payments systems.

- Recent contractual innovations, such as collective action clauses (CACs), will not diminish the impact of the remedy for the foreseeable future, among other reasons because they are not designed to bind the entire debt stock. The Greek debt restructuring, where over half of the foreign-law issues with CACs failed to clear the voting threshold, is a case in point.

- The latest pari passu episode illustrates the challenge of a purely contractual framework for debt restructuring: interpretation uncertainty, institutional barriers to contract change and a well-resourced constituency with every incentive to take advantage of the combination, make for an irreducible risk.

- The options going forward range from contract reform to reviving treaty-based sovereign bankruptcy. The former will be slow and incomplete; the latter has dim political prospects.

- If the District Court decision stands, it strengthens the hand of sovereign bankruptcy proponents.

- This article suggests a combination of contractual and institutional reform as an interim fix for what remains a deeply dysfunctional regime.

\section{Introduction: wages of sin}

Sovereign debt is unenforceable. The law can do little to make an unwilling government pay, or hand over its property to the creditors. To be sure, most governments pay their debts voluntarily; and every so often, a creditor seizes the odd sovereign penny. Nevertheless, the baseline legal regime differs fundamentally for debtors who are immune from enforcement, and for those who are not.

The doctrine of restrictive sovereign immunity obscures this enforcement deficit. It purports to give creditors access to debtors and their assets, most importantly when both

\footnotetext{
* Anna Gelpern, American University Washington College of Law. Thanks to Mitu Gulati, Christoph Trebesch, Mark Weidemaier and Vladimir Werning for valuable insights, and to Peter De Bou for helpful research assistance. Portions of this article are based on CreditSlips.org blog posts.
} 
are in the realm of 'commercial activity'. Since borrowing money in the market is a well-established commercial activity, ${ }^{1}$ sovereign bonds look enforceable to an untrained eye, even though in most cases, there are no commercial assets to satisfy the debt outside the debtor's borders. Things might have been different in the days of state-owned trading firms, when the doctrine came of age, but those days have gone the way of wood-panelled televisions.

The false appearance of enforceability in turn creates what one journalist described to me as a business model: many buy sovereign debt expecting to be paid and, failing that, expecting to enforce their contracts-but discover too late that enforcement requires extraordinary skills, patience, and resources. The many then either agree to deep haircuts or sell to the few enforcement professionals for pennies on the dollar. The few proceed to test the legal system. By definition, theirs are the hard cases prone to make bad law.

Before proceeding to one hard case now pending in the US Court of Appeals for the Second Circuit, it is worth comparing the Looking-Glass world of sovereign debt to the real world, where creditor remedies generally run against the debtor. In the real world, creditors might jockey for position ex ante by demanding collateral or formal priority, reasonably certain that this bargain would stand when the debtor is short on funds. Ex post, creditors might all rush to sue and strip assets, and some would do better than others. These are ordinary coordination failures for which bankruptcy is the dominant institutional response.

If sovereign debt were generally enforceable, such failures would be much more salient, and there would be more pressure for a bankruptcy regime to preserve value and distribute limited resources equitably among the debtor and the creditors. ${ }^{2}$ Immunity goes a long way to deter the rush to sue and strip: it leaves creditors with no steady target or point of leverage, and encourages most to acquiesce in the modification of their contracts. Although the immunity shield is imperfect, it was good enough for decades to help deflect calls for sovereign bankruptcy. But it has also pushed holdouts to use odd theories to recover, while transactional lawyers (for reasons of their own) have preferred indirect ways of patching the fraying contract fabric. ${ }^{3}$ Participants in the sovereign debt market have thus progressively painted themselves into a doctrinal and institutional corner.

The latest case to test the system features the most determined debtor-creditor pairing imaginable. Committed to prove the status quo incapable of producing sensible outcomes, NML Capital (an affiliate of Elliott Associates) is trying to collect from the Republic of Argentina. After defaulting on nearly $\$ 100$ billion in foreign debt in 2001, Argentina exchanged 93 per cent of its old defaulted debt in two operations, in 2005 and

1 See, eg Republic of Argentina v Weltover 504 US 607 (1992).

2 Bankruptcy of course does much more than stop asset grabs and other coordination failures. On sovereign bankruptcy as a response to a broader range of incentive problems and coordination failures, see Patrick Bolton and David A Skeel, Jr, 'Inside the Black Box: How Should a Sovereign Bankruptcy Framework Be Structured?' (2004) 53 Emory LJ 763; for an expansive account of bankruptcy goals outside the sovereign setting, see, eg Elizabeth Warren, 'Bankruptcy Policy' (1987) 54 U Chi L Rev 775.

3 Mitu Gulati and Robert E Scott, The 3 1/2 Minute Transaction: Boilerplate and the Limits of Contract Design (The University of Chicago Press 2012). 
2010, issuing new bonds worth about one-third of the old. NML sat out both times, and sued on the old debt. Characteristically, the fight is not about whether Argentina owes the money, but how NML might collect.

As befits Elliott's reputation for creativity, NML is trying to collect in a most original way. Rather than getting judgments on all its claims, it set aside about $\$ 1.3$ billion in principal and past due interest to seek an equitable remedy for a covenant breach. The covenant in question-the pari passu clause in Argentina's 1994 Fiscal Agency Agreement-promises that NML's bonds, and the payment obligations thereunder, will rank equally with other senior unsecured external indebtedness of the Republic. In NML's reading, now endorsed by the US Federal District Court and the Second Circuit Court of Appeals, the clause forbids Argentina to pay other debts unless it also pays NML pro rata. The District Court accordingly issued an injunction that barred Argentina from paying its restructured debt, and instructed that copies of the injunction be served up the payment chain, to warn third parties against helping Argentina service its new bonds.

The unique significance of the pari passu remedy is that by its very nature, it targets everyone 'but' Argentina. Argentina could do no worse than it has done already: it has refused to pay judgments in favour of the holdouts, and has been squirrelling away its things to avoid seizure. ${ }^{4}$ A country cannot be jailed or held in contempt of court, though it might suffer incremental reputational damage (query the increment here). In contrast, the various market actors heretofore on the sidelines in the fight between Argentina and NML have suddenly become NML's principal targets, levers and opponents.

It is as if the courts were forcing participants in the sovereign debt market to reckon with the necessary implications of its original $\sin ,{ }^{5}$ trading in utterly unenforceable contracts. The market has turned on itself: the few who used to free-ride on the concessions of the many are now attacking the many directly. And so on just one day in January, the Second Circuit received 17 filings from non-party appellants, intervenors, amici and just plain folks on all sides.

The remainder of this article will consider whether and how this moment of reckoning for sovereign debt might lead to its redemption. I begin with an overview of the NML litigation, its antecedents and attempts at indirect contract reform to diffuse the effect of the remedy. I argue that the pending case is likely to produce an important and dysfunctional outcome. In conclusion, I consider three possible responses to the incident: contractual, statutory and institutional, and offer thoughts on the way forward.

4 Most recently this has meant leasing commercial aircraft to fly the President abroad for fear that the presidential plane would be seized. Camila Russo, 'Evading Singer’s Dragnet Means \$880,000 Flight: Argentina Credit' Bloomberg (10 January 2013) <http:// www.bloomberg.com/news/2013-01-10/evading-singer-s-dragnet-means-880-000-flight-argentina-credit.html> accessed $10 \mathrm{March}$ 2013.

5 I use the term to describe the enforcement gap at the foundation of the sovereign debt contracts. Economists have claimed the term 'original sin' for countries' inability to issue debt in their own currencies. Barry Eichengreen and Ricardo Hausmann, 'Exchange Rates and Financial Fragility' (1999) Proceedings, Federal Reserve Bank of Kansas City, 329-68; Barry Eichengreen, Ricardo Hausmann and Ugo Panizza, 'Original Sin: The Pain, the Mystery and the Road to Redemption' (2002) Paper presented at a conference on Currency and Maturity Matchmaking: Redeeming Debt from Original Sin, Inter-American Development Bank $<$ http://www.financialpolicy.org/financedev/hausmann2002.pdf > accessed 10 March 2013. 


\section{Contract hope}

Sovereign debt is the rare natural experiment in contract ordering: without bankruptcy or supranational regulatory authority, debtors and their creditors must rely on contracts to manage their relationships. This accounts for much of the academic interest in the field. Sovereign debt is a place to test the extent to which contracts among highly sophisticated parties can do the work of bankruptcy and other statutory schemes. NML Capital v Argentina $^{6}$ tests two propositions in this vein: first, whether contracts can order inter-creditor relationships equitably without a bankruptcy backstop, and second, whether a purely contractual framework for sovereign debt restructuring can produce sustainable results. So far, the results are disconcerting.

\section{Equality and equity}

The pari passu clause has been in sovereign debt contracts for over a century. In general, it promises that the debt contract which contains it will be on equal footing with some subset of the debtor's other debt contracts. Few agree on what equal footing means or what to do when it becomes unequal. Modern formulations of the clause range from referencing rank alone ('shall rank pari passu with other unsecured unsubordinated external indebtedness') to rank and payment ('shall rank pari passu... and will be paid as such'), with many formulations in between-including Argentina's. ${ }^{7}$

As countless commentators and court filings have observed, the clause makes a lot of sense in bankruptcy, where all debts are due at the same time, where the debtor can be liquidated, and where the proceeds of liquidation can be distributed to the creditors in order of contractual priority under judicial supervision. Pari passu helps ensure that under such circumstances, like claims would be treated alike.

None of the above holds for sovereigns. However, explanations of what the clause means and why it has been included in government debt contracts have been unpersuasive or overtaken by law reform and market practice. In 2000, this apparent uncertainty created an opening for Elliott to claim in a case involving Peru that the pari passu promise required debtors unable to pay all their creditors in full to pay each creditor ratably. That theory, which had never been tested before, was briefly endorsed by a Belgian court, which ruled that funds sent through Euroclear to holders of Peru's restructured bonds had to be blocked unless the holdouts were paid. ${ }^{8}$

Most sovereign debt lawyers characterized the outcome and the underlying theory as problematic at the time: after all, the restructured bond holders had just suffered a deep haircut, without which no one could get paid. Under the banner of formal equality, Elliott was seeking full payment at the restructured bond holders' expense. The Elliott

6 NML Capital Ltd $v$ The Republic of Argentina (2d Cir 26 October 2012) (Nos 12-105(L) etc)

7 Under Argentina's 1994 Fiscal Agency Agreement, 'The Securities will constitute... direct, unconditional, unsecured, and unsubordinated obligations of the Republic and shall at all times rank pari passu and without preference among themselves. The payment obligations of the Republic under the Securities shall at all times rank at least equally with all its other present and future unsecured and unsubordinated External Indebtedness (as defined in this Agreement).'

8 Elliott Assocs, LP, General Docket No 2000/QR/92 (Ct App of Brussels, 8th Chamber, 26 September 2000). 
reading of the clause was also unfair to other holdouts, who did not think of the ratable payment theory in time to share Elliott's payout. To be sure, it is fine for some creditors to do better than others-where there is no comprehensive bankruptcy regime demanding equal treatment, the bigger payout is a reward for hard work and creativity-but it seemed twisted for disparate treatment to be grounded in theories of equality. Market reaction appeared to track the lawyers': sovereign debt spreads rose in response to the decision, perhaps reflecting uncertainty about how distress would be handled from then on. ${ }^{9}$

Critics of the Belgian court decision ${ }^{10}$ protested that the narrow 'rank' meaning of the clause had been settled in the markets, and destabilized by the court's broad 'ratable payment' interpretation. They pointed out among other things that market participants used other terms for ratable payment, occasionally side by side with pari passu. They warned that the broad reading could in theory ensnare payments to multilaterals such as the World Bank and the IMF, and other categories of debt heretofore excluded from restructurings by custom. They pointed to evolving government practices, such as revenue earmarking, which might have justified the use of the clause once upon a time to preserve rank, not to get paid. Nevertheless, critics simply could not come up with a compelling story of why the clause was still there and what it meant at the turn of the twenty-first century.

Anxious about its pending restructuring, Peru settled on terms very favourable to Elliott. Anxious about Euroclear's vulnerability to creditor enforcement actions, Belgium responded with legislation shielding Euroclear from future lawsuits. The case became famous as the rare example of creditor enforcement success, and the meaning of the clause went from irrelevant and forgotten to all-important and hotly contested. Courts in the UK, the USA and elsewhere soon saw similar claims, including Elliott's attempts to collect from Nicaragua and Congo on the pari passu theory. Although no court clearly endorsed the ratable payment remedy and some disavowed it, the sum total of the decisions and settlements added to the interpretive fog.

The Belgian court decision and the cases that followed made for a policy dilemma. They highlighted the vulnerability of a contract framework where admittedly indeterminate terms can be used 'off-label' to overcome immunity. The episode featured prominently in the IMF officials' case for a treaty-based Sovereign Debt Restructuring Mechanism (SDRM). ${ }^{11}$ While it strengthened the hand of SDRM proponents, Elliott $v$ Peru created big problems for those who had doubled down on contracts as the way forward for sovereign debt. If a treaty regime were not to be, continued availability of the

9 Michael Bradley, James D Cox and Mitu Gulati, 'The Market Reaction to Legal Shocks and Their Antidotes' (2010) 39 J Legal Studies 289.

10 Prominent criticisms include Financial Markets Law Comm (Bank of England), 'Pari Passu Clauses: Analysis of the Role, Use and Meaning of Pari Passu Clauses in Sovereign Debt Obligations as a Matter of English Law' (2005); Lee C Buchheit and Jeremiah S Pam, 'The Pari Passu Clause in Sovereign Debt Instruments' (2004) 53 Emory LJ 869; G Mitu Gulati and Kenneth N Klee, 'Sovereign Piracy' (2001) 56 Bus Law 635. For a comprehensive overview of the criticisms, see Gulati and Scott (n 3).

11 For an authoritative account of the SDRM initiative, see Sean Hagan, 'Designing a Legal Framework to Restructure Sovereign Debt' (2005) 36 Geo J Int'l L 299. 
pari passu remedy created uncertainty about restructurings and exposure for the infrastructure of the global financial system.

Since its successful invocation in 2000, arguments about the incentive effects of the pari passu remedy have caused a surprising lot of confusion on all sides. Officials and academics routinely claim that when Elliott and the like are paid in full under the broad reading of pari passu, others are encouraged to hold out the next time. ${ }^{12}$ Despite anecdotal accounts of would-be holdouts who bought Argentina's debt after Elliott $v$ Peru, there has been no hard evidence of a shift in creditor behaviour. Investors counter that even with the pari passu remedy, holding out and litigating for years against immune sovereigns and global clearing houses is simply too hard and expensive, and is understood in the market not to be a widely replicable business model. They say that the vast majority of investors would prefer the certainty of 30 cents today to the prospect of 100 cents years later, especially considering the detective and legal costs involved. If the threat of holdout lawsuits helps prod the sovereign debtor to a higher offer, the rest are all the happierbut they do not want to do the work themselves.

In the world of ratable payment, both sides of the argument are beside the point. The choice on the table is not between 30 cents now and maybe 100 cents later. It is between 30 cents now 'plus' being ensnared in injunctions-and maybe 100 cents later. Put differently, holding out is still unattractive. But the pari passu ruling has made participation unattractive as well. Creditors who have no appetite to sue surely do not want to be sued. The same holds for financial market intermediaries, such as trustees, paying agents and clearing houses.

While the availability and contours of pari passu as a remedy remained in limbo after Peru, the question of its incidence became important. If there were to be ratable payment, would it be granted any time a holdout chose to sue, or only in a few egregious cases that should be of no concern to the market mainstream (such as it was)? This is where Argentina comes in.

Argentina defaulted on its debt in late 2001, amid a devastating financial and economic crisis. It took nearly four years to consummate a debt exchange, which featured the customary strong-arming of domestic regulated institutions, deep haircuts and unusually hardball negotiations that left even the most jaded creditors feeling bruised. ${ }^{13}$ In late 2003, shortly after Argentina put its first restructuring offer to the bond holders, ${ }^{14}$ some judgment creditors hinted that they might try to collect using a pari passu theory. A fund affiliated with Kenneth Dart (like Elliott, an experienced enforcer) was among those leading the charge; NML joined relatively late, and without a judgment in hand. ${ }^{15}$ Argentina immediately sought a ruling affirming a narrow interpretation of pari passu, helped by strongly worded briefs from the Bush Administration, the Federal Reserve Bank

12 See, eg NML Capital $v$ The Republic of Argentina, Proposed Amicus Brief of Anne Krueger in Support of Reversal (4 January 2013).

13 Arturo C Porzecanski, 'From Rogue Creditors to Rogue Debtors: Implications of Argentina's Default' (2005) 6 Chi J Int L 311.

14 The offer came in September, several months after SDRM had been shelved in favour of contract reform.

15 EM Ltd et al $v$ Republic of Argentina Hearing Transcript (SDNY 15 January 2004) (No 02-cv-1773-TPG). 
of New York and the New York Clearing House Association. ${ }^{16}$ The creditors said that the matter was not ripe for adjudication, since they had not actually invoked pari passu. The court agreed.

Argentina proceeded with its restructuring in 2005. ${ }^{17}$ Apparently to facilitate the operation, the government enacted domestic legislation (the 'Lock Law'), which barred the Executive from settling with holdouts. Just over three-quarters of all creditors signed up in the first round. In 2010, the law was temporarily suspended to sweep in those who had given up on holding out. In all, 93 per cent of the old bond holders had gone into the restructuring. Meanwhile, the meaning and import of pari passu remained in suspense, even as academics, practitioners, market and policy types sought to put their respective spin on it.

It took six more years for the other shoe to drop. By 2011, Argentina began to look less like a crisis-stricken victim and more like a repeat offender. Multiple judgments had been entered; none had been paid. The senior judge presiding over the many cases brought against the Republic in the Southern District of New York took to issuing opinions with underscored text stating the obvious:

Stepping back a bit, it should be noted that the bulk of the litigation has been devoted to the question of finding assets to attach or execute on because the Republic will not pay the judgments. But little has been said about the underlying, fundamental fact that the Republic has the duty to pay these judgments. A judgment debtor has an obligation to pay. ${ }^{18}$

Judge Thomas Griesa's new willingness to grant extraordinary remedies-such as attaching foreign central bank funds on deposit at the Federal Reserve Bank of New York and intended to pay the IMF_-ran up against appellate courts' reluctance to let outrage at Argentina subvert immunity and other settled doctrines. ${ }^{19}$ The fact that creditors sought to enlist in their collection effort a growing number of actors at the heart of the global financial system, such as central banks and international institutions, pushed reluctant allies into Argentina's camp.

But beyond the courtroom, patience with the Republic was wearing thin. At home, the crisis mode continued to frame the government's posture. Outside Argentina, memories of its crisis had faded, replaced by crises in the USA and Europe. Argentina's refusal to pay judgments and arbitral awards, and its spree of expropriations, prompted US and European governments to consider trade measures and vote against multilateral loans to Argentina.

By December 2011, Judge Griesa-who had previously expressed scepticism about the pari passu remedy and the Belgian court decision-was ready to give it another chance.

16 Briefs of the USA, the Federal Reserve Bank of New York and the The Clearing House Association LLC in Macrotecnic International Corp et al $v$ The Republic of Argentina (SDNY 12 January 2004) (No 02-cv-5932-TPG).

17 The operation was stalled for a couple of months by NML and EM attempts to seize defaulted bonds tendered in the exchange, as marketable property of Argentina. For an account of the exchange, see Anna Gelpern, 'After Argentina' (Inst for Int'l Econ, Policy Brief No PB05-02, 2005).

18 EM Ltd et al $v$ The Republic of Argentina (SDNY 7 April 2010) (No 03-civ-2507-TPG) 12 (emphasis in the original). The same opinion referred to the Lock Law as codified repudiation.

19 NML Capital, Ltd v Banco Central de la República Argentina (2d Cir 5 July 2011) (No 10-1487- cv(L), 2011 WL 2611269 ). 
He ruled that Argentina's persistent refusal to pay, including but not limited to its codification in the Lock Law, amounted to a pari passu violation under the bonds held by NML. ${ }^{20}$ On 23 February 2012, he granted an injunction directing Argentina not to pay its restructured debt or change payment arrangements to circumvent the court order, unless it paid NML. The Judge directed that copies of his injunction be served on all involved in the payment process, to prevent trustees, paying agents, clearing systems and advisors from facilitating payment on the still-performing debt. As he was ruling for the creditors, Judge Griesa seemed to suggest he expected to be reversed. ${ }^{21}$ But by then, the goal had become to give creditors leverage-any leverage, it seems_-and to recapture some dignity for the court itself, now feeling slighted and ignored.

Even though the February pari passu ruling was precisely the bombshell for which the sovereign debt market had been preparing over a decade-a definitive interpretation from New York or London-the market response was muted to none. ${ }^{22}$ It is hard to tell whether this was because everyone expected Argentina to settle, or, along with Judge Griesa, expected a reversal on appeal. The fact that the decision was stayed may have made it a problem for another day.

The much-anticipated appellate hearing similarly did not change expectations. Argentina bore the brunt of judicial questioning, but a decision against it still looked like a tall order at the time: to sustain the injunction, the court had to decide the meaning of the pari passu clause, decide that failure to pay NML pari passu was an irreparable injury distinct from failure to pay, decide that telling Argentina how to spend its Treasury funds did not amount to restraining immune property in Buenos Aires, and-perhaps most importantly-accept the certainty that plaintiffs' lawyers would target financial institutions in New York as proxies for still-unreachable Argentina. Plaintiffs' counsel promised as much in the hearing. It would seem far easier for the court to excoriate Argentina and bemoan the state of sovereign immunity.

Those who thought that this experiment in holdout enforcement would go the way of the others also pointed to the US intervention arguing for reversal. The Obama Justice Department revived arguments made by its predecessor in 2004 on the meaning of pari passu, and added more on the harms of injunctive relief purporting to restrain foreign sovereign expenditures. The intervention was a minor miracle and clearly a hard call, made transparent by the brief's opening condemnation of Argentina's lawless ways. The US government had just suspended the Republic's trade privileges, was voting against it in the multilaterals, and considering sanctions against it in the IMF board for reporting violations. It bristled at the idea of being associated with a debtor thumbing its nose at the system. It even seemed to have its doubts on the merits: in the brief and oral argument

20 Unlike its predecessors in 2004, NML refrained from getting a judgment, which might have precluded its reliance on a contract clause under the merger doctrine.

21 The passages expressing self-doubt are quoted at length in the Brief of Exchange Bondholders Opposing the Injunction in NML Capital v The Republic of Argentina (28 December 2012).

22 Vladimir Werning, 'EMTA Seminar: Recent Legal Developments in Argentine Debt, Market Reaction: Implications for the Market' Presentation (7 January 2012). 
alike, the USA demurred on whether the Lock Law violated pari passu. Nonetheless, concerns about immunity and the sovereign debt restructuring regime prevailed. The New York Clearing House Association intervened as well, largely reprising its position in 2004. In contrast, the New York Fed decided to sit this one out at first, perhaps because it had done the heavy lifting deflecting the holdouts' attempt to seize Argentine central bank funds in 2010-or because it was done with Argentina.

As it turns out, the Second Circuit was done with Argentina. On 26 October 2012, after characterizing the case as a matter of straight-up contract interpretation, the appeals court ruled that the market understanding of pari passu was unsettled, and that the second sentence of Argentina's clause bound it 'as payor' not to discriminate among its creditorsglossing over the fact that even in that sentence, the promise was to rank, not to pay. Significantly, the appeals court refused to hang its decision on the Lock Law alone, but listed six years of non-payment, US securities disclosure stating that the Republic would not pay the holdouts, statements by government officials, Argentine budget legislation and the Lock Law to illustrate a pattern of discrimination that amounted to breach. The court also observed that in the 2003-2004 round of pari passu arguments, Argentina had not yet violated the clause by persistent discrimination, including the Lock Law.

In short, the circuit panel seemed to have no doubt whatsoever about the merits. ${ }^{23}$ The remedy was another matter. Here the panel repeatedly expressed concern about the injunction's application 'to third parties generally' and said it was 'unable to discern' how Judge Griesa's ratable payment formula would work. The case was thus remanded in part back to Judge Griesa, and set to return automatically to the appeals panel after he had done his work.

This was the real earthquake. Spreads on Argentina's restructured New York-law debt shot straight up, along with the price of credit default swaps, suggesting that creditors now perceived it to be riskier than debt issued under Argentine law. On the other hand, there was no immediately apparent effect on other issuers, even those that were in distress at the time.

Then things got puzzling. On November 9, Judge Griesa held a hearing to follow up on the circuit court decision - and yet again seemed beyond exasperated with Argentina. The plaintiffs argued, and the Judge seemed to accept, that partial affirmance on appeal meant total vindication. The Judge showed no patience for the restructured bond holders (who claimed to be held 'hostage' by NML), and various intermediaries and bystanders scrambling to intervene at the 11th hour. Everyone got just a few days to submit their briefs, as the judge promised to lift the stay on his injunctions in time for NML to

23 The panel brushed off the US argument under the Foreign Sovereign Immunities Act on the grounds that unlike the Brussels court, which sought to take property, the US District Court was merely telling Argentina what to do-a hyper-literal reading of the text. In contrast, the court appeared to disregard the text when it dismissed concerns that the District Court order swept in payments to international organizations with informal preferred creditor status. It said that everyone understood the IMF to be special, and in any event, the plaintiffs were not targeting it just now.

Only a few years earlier, when the plaintiffs did try to intercept a payment to the IMF, the Second Circuit had ruled that such payments were not commercial activity. Moreover, their special structure may exclude them from the contractual definition of 'external indebtedness' for purposes of the pari passu clause. However, the same may not apply to transactions with the World Bank. The October ruling itself highlights the fact that asset immunity is at best a partial shield against injunctive relief. 
intercept December payments. ${ }^{24}$ Half a dozen new submissions followed within a week, this time including a letter from the New York Fed asking the court to take payment and clearing systems out of the target zone and a letter from Bank of New York Mellon as trustee, asking to be left out (or failing that, asking for instructions on reconciling its conflicting legal duties). On November 21, the Wednesday before the US Thanksgiving holiday, Judge Griesa issued an amended order and two opinions essentially giving NML everything. The ratable payment formula would have Argentina pay NML its entire accelerated principal and past due interest whenever the restructured bond holders got their full coupon payment. Trustees and clearing systems (including Belgium's Euroclear) were swept in as parties 'in active concert or participation' with Argentina, ignoring the New York Fed's specific request to exempt the latter and Bank of New York Mellon's plea for cover. The stay was lifted effective December. And if Argentina wanted to pay the new bond holders, it would have to put money into an escrow account for the benefit of NML. ${ }^{25}$ Argentine debt spreads jumped again.

For the Circuit Court panel awaiting automatic return of the case, the revised order promised a headache. Judge Griesa took the questions the panel called difficult, called them easy, and summarily dispensed with them in favour of NML. If what they wanted was more support for a hard decision, the judges did not get it. On November 28, the appeals panel put everything on hold. It revived the stay, set a briefing schedule into the New Year, and scheduled a hearing for 27 February 2013. It also granted just about every request to intervene, in whatever capacity, to the various market intermediaries and creditors of Argentina. The panel received over two dozen third-party briefs and motions on the design and application of the pari passu remedy, including doctrinal and policy arguments on the role of indenture trustees in the financial markets, an intricate treatment of the Uniform Commercial Code's funds transfer provisions, and a 'heads up' from EM Ltd that it would seek to expand the remedy to judgment debt.

The Circuit Court reaction to Judge Griesa's dismissal of its concerns is important for its speed and apparent willingness to hear everyone out-though one would be hard pressed to forecast a reversal considering the scope and conviction of the panel's October decision. The desire to punish Argentina and the feeling that sovereign immunity taken to its logical extreme is making the court system look feckless may trump all other concerns in the end. 
Apart from the drama surrounding the equitable remedy, the US government joined Argentina in requesting a rehearing en banc, so that the full Second Circuit could review the decision on the merits as to the meaning of the clause. Contrary to reports suggesting that the intervention was another bit of official dithering, it makes more sense to read the US brief as a sign of serious policy concern. The government picked the broadest available grounds for intervention despite its continued public disagreement with Argentina. It is hard to tell whether the Administration is more worried about the future of restructurings in the shadow of pari passu, or the risk of an SDRM revival-although the two are obviously related. In addition to the arguments in its earlier brief, the USA made clear that it could live with a ruling that more clearly limited the fallout to Argentina, for example, by tying the ruling more closely to the Lock Law. In the past, US intervention secured an en banc review in one sovereign debt case (coincidentally decided by Judge Griesa in the first instance). Nevertheless, a rehearing remains statistically unlikely: the Second Circuit ruled en banc in only eight cases between 2000 and 2010 (less than 0.03 per cent of its total case load); it grants far fewer such rehearings than other regional circuits. ${ }^{26}$ Perhaps the best outcome for Argentina would be a denial with a dissent that might help get its case before the US Supreme Court.

\section{$* * *$}

What to make of this improbable journey? A once-forgotten contract clause, whose drafters systematically disclaim paternity and profess not to know its meaning, is poised to give holdouts the most potent weapon in modern memory. Viewed within the confines of the contract, the clause is susceptible to multiple interpretations, including ratable payment. ${ }^{27}$ Holdouts have every incentive to leverage interpretation in a world where debtors' assets are unreachable, where contract enforcement is the exception brought about by a few experts, and where debt collection requires free-riding on the concessions of those who cannot (or would not) enforce. The unique power of pari passu as ratable payment injunction is in its capacity to inflict collateral damage far beyond the contract in which the clause resides, notably on financial market infrastructure. Unchecked by bankruptcy policy, creative contract interpretation is the logical and last best hope of those hoping to collect from an immune debtor. But contracts can change.

\section{Coordination cures and process for all}

Ten years ago, collective action clauses (CACs) were introduced on a large scale in sovereign bond contracts governed by New York law. This is the most impressive and puzzling episode in sovereign debt contract, and possibly all boilerplate, reform. It is impressive because the change happened across the entire market overnight: soon after Mexico's pioneering issue in February 2003, three-quarters of all new sovereign bond issues gave up on clauses requiring unanimous bondholder approval to amend financial 
terms, and chose instead clauses permitting supermajority amendment, along with a smattering of others designed to promote coordination in restructuring. By 2010, over 90 per cent of all new issues had CACs. ${ }^{28}$ The episode is puzzling because most of those promoting and adopting CACs insisted at the time that they would not make much of a difference in the handling of sovereign debt distress, or reduce the demand for multilateral bailouts - though all agreed that they would help make restructuring smoother on the margins. ${ }^{29}$ Although indirectly justified by fear of holdouts in the wake of Elliott $v$ Peru and Argentina's default in 2001, the advent of CACs is most closely tied to officials' and market participants' desire to preempt the IMF's statutory sovereign bankruptcy initiative.

CACs were supposed to be the contract fix to holdout problems that made SDRM superfluous. Supermajority voting, long prevalent in English-law bonds, is the best known and most widespread CAC. Like analogous bankruptcy mechanisms, it 'crams down' the terms of a restructuring on all bondholders despite the dissenting minority. Most CACs operate on individual bond series. To restructure multiple issues, the debtor must hold separate and independent votes, typically securing 75 per cent bondholder support for each. In this scenario, minorities of just over 25 per cent could block restructuring of their bond and hold out. The voting threshold can apply either to the outstanding principal to be amended (typical for written ballots) or to the outstanding principal for bonds represented at a quorate meeting (in-person voting). Bonds held by the debtor and those it owns or controls are often excluded from the vote; however, regulated institutions are not normally disenfranchised.

A few countries, beginning with Uruguay in 2003, have provisions that allow for cross-series modification (aggregation) where multiple issues can be amended together with a double voting threshold: for example, 85 per cent of principal outstanding across the solicited series, and $66 \frac{2}{3}$ per cent of each series. Where 34 per cent of a series fails to back modification, that series drops out but the rest go forward. Although it has been very rare to date, aggregation is gaining traction as a leading market association has backed it as part of its package of contract reforms, ${ }^{30}$ and European governments have committed in the treaty establishing the European Stability Mechanism to adopt CACs with aggregation in their domestic-law bonds. ${ }^{31}$

Other rare forms of CACs include limits on individual creditors' rights to accelerate and litigate, and clauses that help initiate a restructuring. ${ }^{32}$ But the vast bulk of the revolution has been in issue-by-issue supermajority amendment.

28 See Michael Bradley and Mitu Gulati, 'Collective Action Clauses for the Eurozone' (draft dated 7 May 2011) <http://papers. ssrn.com/sol3/papers.cfm?abstract_id=1948534> accessed 10 March 2013.

29 Anna Gelpern and Mitu Gulati, 'Public Symbol in Private Contracts: A Case Study' (2006) 84 Wash U L R 1627.

30 International Capital Market Association (ICMA), 'ICMA Sovereign Bond Consultation Paper' (23 November 2010).

31 For an overview of the European initiatives, see EFC Sub-Committee on EU Sovereign Debt Markets, Collective Action Clauses in Euro Area <http://europa.eu/efc/sub_committee/cac/index_en.htm> accessed 10 March 2013.

32 W Mark C Weidemaier and Mitu Gulati, 'A People's History of Collective Action Clauses' (draft dated 7 November 2012) $<$ http://papers.ssrn.com/sol3/papers.cfm?abstract_id=2172302> accessed 10 March 2013; John B Taylor, 'Under Sec'y of Treasury for Int'l Affairs, Sovereign Debt Restructuring: A US Perspective, Speech at the Conference on "Sovereign Debt Workouts: Hopes and Hazards," Institute for International Economics' (2 April 2002); W Mark C Weidemaier and Mitu Gulati, 'How Markets Work: The Lawyer's Version' (15 July 2011) <http://scholarship.law.duke.edu/faculty_scholarship/2425> accessed 10 March 2013. 
In gauging the impact of the revolution, it is also important not to confuse CACs in new issues with CACs in the outstanding debt stock. Bonds issued under New York law before 2003 still require unanimous consent to amend key terms. Some of this debt has long original maturities and will remain outstanding for some time. There is no authoritative data on the prevalence of CACs across outstanding debt stock, though doubtless it is rising fast.

Like the reinvigorated pari passu clause, CACs are a contractual fix for a structural flaw in the sovereign debt regime. Where there is no bankruptcy, supermajority voting can help reduce the incidence of holdouts and facilitate restructuring. As with pari passu, CACs are a limited fix and a blunt tool, called upon to carry a lot more weight than they were designed to carry, and vulnerable to confusion about what they do.

In addition to giving the debtor a roadmap to debt relief, CACs can help would-be holdouts to identify bond issues where they can secure blocking positions. For example, it would take just over $\$ 25$ million to block restructuring in a $\$ 500$-million issue trading at 20 cents on the dollar with a 75 per cent CAC threshold. One adviser to investors who held out in the Greek restructuring in March 2012 explained that CACs made the process more predictable for his clients. The fact that CAC votes were attempted for 36 foreign law issues in the Greek restructuring, and failed in 19 of these, supports this account. ${ }^{33} \mathrm{~A}$ restructuring under unanimity may be more chaotic and uncertain, calling forth strong arm negotiating and aggressive transactional techniques such as exit consents. ${ }^{34}$ To the extent a sovereign commits to rely on CACs for its restructuring process, that process becomes more predictable for all-the debtor, the participating creditors and the holdout.

Adding to the confusion, CACs have shown outsize rhetorical power: in market, policy and media circles alike, they have come to evoke an orderly and market-friendly restructuring process bound to secure debt relief for the sovereign and keep creditors happy. Perhaps the most ironic illustration of this power also comes from Greece. On the eve of its restructuring, the Greek parliament enacted a law that retroactively inserted a voting mechanism in its domestic law bonds, permitting two-thirds of a bondholder quorum to bind the rest. The quorum was set at 50 per cent. This mechanism became known as the 'retro-CAC' and was spectacularly successful, combined with other tactics, in securing large-scale participation in the Greek exchange. Of course the mechanism itself had little in common with contractual CACs. It was mandated ex post by statute, and relied on a single cross-series vote with thresholds far below the market norm for negotiated CACs, with a large number of Greek and European regulated institutions certain to participate. This went beyond traditional aggregation, since individual issues

\footnotetext{
33 Jeromin Zettelmeyer, Christoph Trebesch and Mitu Gulati, 'The Greek Debt Exchange: An Autopsy' Working Paper (11 September 2012) <http://papers.ssrn.com/sol3/papers.cfm?abstract_id=2144932> accessed 10 March 2013.

34 Lee C Buchheit and G Mitu Gulati, 'Exit Consents in Sovereign Bond Exchanges' (2000) 48 UCLA L Rev 59; Ran Bi, Marcos Chamon and Jeromin Zettelmeyer, 'The Problem that Wasn't: Coordination Failures in Sovereign Debt Restructurings' (Int'l Monetary Fund, Working Paper No 11/265, 2011).
} 
could not drop out. Why was this voting mechanism called 'retro-CAC' (or anything CAC for that matter)? Presumably to signify that an otherwise radical restructuring technique was of a piece with the relatively innocuous one, well-known and accepted in the market as a counterweight to statutory bankruptcy. Judging by the way the name stuck, the strategy was successful-helping both Greece and CACs.

The final bit of confusion about CACs emerged from NML $v$ Argentina, and goes to CACs' relationship to the pari passu remedy. The plaintiffs, some amici, the Second Circuit and respected media outlets have said that once CACs are adopted in all bonds, the pari passu remedy would become irrelevant because holdouts would disappear. Since most new issues contain CACs, the big debate between the proponents and critics of the Second Circuit's reasoning surrounds the transition period: the volume of bonds outstanding without CACs, and their residual maturity. Neither is known with certainty. This debate appears to miss both the lessons of Greece, and the essential mechanism by which CACs operate. These clauses are not designed to eliminate holdouts by any means necessary nor to protect creditors participating in an exchange from a lone holdout armed with a nuclear remedy-especially when the holdout sues under a contract wholly apart from theirs. Most CACs are meant to give a large majority of bondholders under a given instrument a voice on the terms of a restructuring, which includes giving those who mobilize a blocking position the capacity to sit out. In this sense, CACs are quite different from bankruptcy cram-down techniques.

As a result, even if every single sovereign bond had CACs, and even if some or all such CACs had aggregation features of the sort used by Uruguay and others, holdouts would (and arguably should) retain the capacity to buy small 'orphan' bond issues at a deep discount and keep them out of restructurings when they do not like the terms. Moreover, to the extent the debtor has obligations that are not in the form of bonds, these too are unlikely to have CACs, and could be kept out.

Whether creditors who mobilize a blocking position in a bond issue, or those who hold out using instruments other than bonds with CACs, should also have access to the new pari passu remedy is a distinct question. If the ratable payment injunction stays, would-be holdouts will have plenty of instruments from which to deploy it for the foreseeable future.

Things could be different with more aggressive forms of CACs. A single series cannot drop out under the mechanism established by the Greek bondholder law, mandating a single cross-series vote. Institutionalizing this approach in contracts appears to be the thrust of ICMA's 2010 reform proposal (albeit at a more creditor-friendly threshold of 85 per cent). ${ }^{35}$ Similarly, the new bonds that came out of the Greek exchange preclude dropouts, at least for the moment, by deeming all exit instruments a single series for purposes of cross-series modification. ${ }^{36}$ These mechanisms do not appear to have been adopted elsewhere in the sovereign debt market to date. 
If CACs' relevance against holdout remedies is so limited, why then have they played such an outsize role in the New York litigation? It is hard to know for sure, but the reason may have something in common with answers to another question: if the markets were worried about pari passu, why have they not eliminated the clause, the same way as they had eliminated unanimous consent to modification? Put differently, why did market participants choose to revolutionize a clause that was neither a big problem nor an important solution for sovereign debt restructuring problems, but refused to change another clause that had caused repeated market shocks? Contrary to the markets' professed outrage with the Brussels decision in 2000, pari passu had been revised in small ways since to make it harder to change and more vulnerable to the ratable payment interpretation. As part of CAC reform, pari passu can no longer be amended by a simple majority vote; meanwhile more and more countries (notably including Italy and Cyprus) have formulations that reference payment.

A recent study attributes failure to change pari passu to agency problems, institutional and cultural factors in the legal profession. Lawyers seem to prefer indirect patches to confronting big problems and their own mistakes head on. ${ }^{37}$ Policy makers and market participants may be prone to similar behaviour, though for different reasons. CACs are attractive precisely because in practice, they are a relatively limited measure. Symbolically, they invoke bankruptcy cramdown, even though they do not come close to its comprehensive effect or equitable safeguards. CACs solve a discrete theoretical problem (creditor coordination failures), albeit one that is already partly solved by sovereign immunity and other transactional techniques. Best of all, thanks to tireless official advocacy in the 1990s and early 2000s, CACs exist and are widely understood to be somewhat helpful and largely harmless, whatever they do. In contrast, once pari passu has become an effective remedy, taking it away requires confronting the enforcement deficit and the empty promise of equal treatment-whatever it means in sovereign debt.

\section{$* * *$}

CACs are perhaps the most successful instance of contract reform in decades. They are doubtless a useful innovation. However, their success may be due at least in part to their modest impact on the sovereign debt restructuring regime notwithstanding their outsize symbolic profile. Paradoxically, even though lawyers, policy makers and market participants had identified the pari passu clause as a clear source of vulnerability that could benefit from reform, it was the voting provisions that got the attention and the resources for change. The reform experience, along with ongoing confusion (some of it no doubt opportunistic) about the relationship between CACs and pari passu in the NML litigation, suggests that a substantive shift in the contract regime remains unlikely. 


\section{Sovereign redemption: what is to be done?}

If the District Court holding in NML Capital $v$ Argentina withstands the next round of appellate review, it will strengthen the hand of bankruptcy proponents. The prevailing regime for restructuring sovereign debt will have revealed itself as prone to whiplash, from no enforcement to highly potent sanctions that rely on collateral damage. It bears emphasis that even if NML and its fellow holdout creditors were to win a complete victory on the injunction, they would not necessarily get paid if Argentina chose not to pay them, especially if Argentina is willing to default on its performing bond holders. The funds Argentina sends to the latter group might be rejected, or caught in the sort of filters that screen for terrorist financing in the payments system, and frozen midstream-with more fog to follow. ${ }^{38}$ The episode illustrates the challenge of a purely contractual framework for debt restructuring: interpretation uncertainty, institutional barriers to contract change, and a well-resourced constituency with every incentive to take advantage of the combination, together ensure a succession of interpretive and market shocks.

Future sovereign defendants will no doubt try to distinguish themselves from Argentina, and would certainly refrain from passing their own versions of the Lock Law. However, despite the invective against the Republic, nothing in the opinions so far limits their application to Argentina's unique facts. ${ }^{39}$ Those who welcome the latest rulings as a long-overdue vindication of creditor rights and court powers have a hard time drawing the line between 'rogue debtors' and the rest-while Argentina certainly clears the bar, it seems you know them when you see them. As this issue went to print, Taiwan had followed in NML's footsteps, invoking the pari passu clause in a debt enforcement action against Grenada. ${ }^{40}$

The appeals court could still pare back the remedy, in the extreme, to make it toothless even with respect to the indenture trustee, the first step in the payment chain-or accept a bankruptcy-style reading of equal treatment, where NML would be paid on the terms of Argentina's debt exchange while looking for other means to enforce the rest of its claim. Although this case has been full of surprises, such outcomes seem unlikely at this stage. A reasonably robust version of pari passu is here to stay, effectively binding market participants, intermediaries and infrastructure providers together in the flawed enterprise of sovereign debt.

There are three kinds of responses to this outcome. First, and most likely, market and policy actors will advocate more contract reform. It is possible that the establishment will find the courage to confront the pari passu clause directly; however, if history is a guide, it is more likely to double down on CACs and promote aggregation. Aggregation certainly

38 See NML Capital v Argentina, Amicus Brief of Ronald Mann and EM Ltd in Support of Affirmance (4 January 2013) (discussing the operation of injunctions against beneficiary's bank under the Uniform Commercial Code in the USA); Amicus Brief of The Clearing House Association LLC in Support of Reversal (4 January 2013) (on the operation of terrorist finance filters).

39 The US Government hinted at a possible route for limiting the impact to Argentina and its Lock Law in $\mathrm{n} 2$ of its brief advocating a rehearing en banc.

40 The Export-Import Bank of the Republic of China v. Grenada, Complaint, 4 March 2010, available at <http://ftalphaville.ft. com/files/2013/03/13cv014501.pdf> accessed 10 March 2013. 
improves on the traditional CACs' capacity to bind holdouts, though in its current form, it does not eliminate them entirely. Recent experience with contract reform suggests that the new clauses are unlikely to be standardized unless adopted by treaty and developed by official institutions, as with CACs in Europe. This leaves residual uncertainty about how they might work and how effective they might be.

Second, many will surely call for the revival of SDRM. After NML $v$ Argentina, there will be much to recommend it. As last proposed in 2003, SDRM would have covered all foreign law debt of the issuer, and would have made dropping out nearly impossible for individual instruments. Nevertheless, the political prospects for SDRM remain dim. It is hard to see the USA, which holds a blocking position at the IMF, changing its view in light of the immensely challenging Congressional politics. Market participants will resist any statutory regime with a role for the IMF (however limited) and take their chances with suing or being sued in a future restructuring. Erstwhile NGO supporters of SDRM appear to have grown more sceptical about IMF involvement over the past decade on governance grounds. On the other hand, treaty-based debt restructuring reforms in Europe may help make the idea of a statutory regime more concrete, prompt useful institutional experimentation and lead to wider acceptance.

The third set of responses goes directly to the pari passu remedy and the institutions it affects. Payment and clearing systems operators such as Euroclear, DTCC and the Federal Reserve could condition access to their services on eliminating or revising the pari passu clause in sovereign debt instruments to reduce such systems' vulnerability to injunctions. Such measures are not unprecedented: access to stock exchanges and clearing platforms has always been conditional, and has been used in the past to promote creditor collective action and debt repayment alike. ${ }^{41}$ Belgium's response to Elliott $v$ Peru was in a similar vein: it amended existing legislation to fortify Euroclear's immunity against attacks targeting its participants and their customers. If it were driven by market infrastructure operators, pari passu reform would protect them directly, and have positive spillover effects on other parts of the sovereign debt market. Uniformity is more likely under these circumstances, because contract language could be prescribed as a condition of access. This approach would be more direct and effective at limiting collateral damage from pari passu as ratable payment than further experimentation with CACs (however sensible on other grounds). CAC reform would have to rely on more finance ministry exhortations and renewed threats of SDRM to change parts of the bond contract that may or may not address the ratable payment remedy or its impact on financial market infrastructure.

Some combination of institutional and contractual intervention would patch the pari passu problem. It would not fix fundamental flaws in sovereign debt: unenforceable contracts and the lack of a comprehensive restructuring regime capable of delivering autonomy and a fresh start to the debtor, and certainty to the creditors. From this perspective, sovereign redemption is nowhere in sight.

41 See, eg Marc Flandreau, 'Collective Action Clauses before they Had Airplanes: Bondholder Committees and the London Stock Exchange in the 19th Century' (4 November 2012) (working paper on file with author). 